\title{
Meta-Analisis Pengaruh Model Pembelajaran Problem Based Learning Terhadap Kemampuan Berpikir Kritis Siswa
}

\author{
Ananda Mahaputra Iskandar ${ }^{*}$, Dinda Nurfadiah, Widia Iswari Yuli, Desnita \\ Pendidikan Fisika, Universitas Negeri Padang \\ *Email: putraiskandar0511@gmail.com
}

Received: 26 Mei 2021; $\quad$ Accepted: 28 Juni 2021; $\quad$ Published: 30 Juni 2021

DOI: http://dx.doi.org/10.29303/jpft.v7i1.2714

\begin{abstract}
This meta-analysis research was conducted with several objectives. First is analyzing that influence given by the problem-based learning model of students' critical thinking skills. Second is to analyze the magnitude of the influence exerted by the problem based learning model based on the level of education (SMA and SMP). The third is to review the magnitude of the influence of using the problembased learning model based on the material being taught (Work and Energy, Fluid, Substance Pressure, Motion, Elasticity, Harmonic Vibration, Electric Current and Electrical Resistance, Temperature and Heat). The fourth examines the magnitude of the influence of the problem-based learning model based on grade levels (VII, VIII, X and XI). The method used in this research is meta-analysis, which is to analyze 20 articles from existing research. Obtained 4 effect size values from the research that has been done. For the effect size, the ability to think critically is 2.25 which is in the high category. Aspect effect size based on the level of education is 2.43 for SMA level. The effect size for the aspect based on the material is 2.99 for the fluid material and the effect size for the aspect based on the grade level is 3.33 at grade XI level.
\end{abstract}

Keywords: Problem based learning; Critical Thinking

\section{PENDAHULUAN}

Saat ini, sebagian besar sekolah di Indonesia sudah menggunakan kurikulum 2013. Salah satu kemampuan yang dituntut oleh kurikulum 2013 adalah kemampuan berpikir kritis. Dalam (Arifin et al, 2020) mengatakan bahwa berpikir kritis merupakan kegiatan menganalisis suatu ide kearah yang lebih spesifik, membedakan secara tajam, memilih, mengidentifikasi, mengkaji dan mengembangkannya kearah yang lebih sempurna. Keterampilan komunikasi, kolaborasi, kesadaran global, penguasaan teknologi, keterampilan hidup dan karier, keterampilan belajar dan inovasi memerlukan landasan berpikir kritis yang baik.

Pembelajaran yang berlangsung di Indonesia saat ini masih jauh dari pembelajaran yang diharapkan kurikulum 2013, dimana pembelajaran yang berlangsung masih berpusat pada guru dan siswa cenderung pasif selama proses belajar. Dalam (Yulianti \& Indra 2019) menyebutkan bahwa berdasarkan hasil pra penelitian dan wawancara guru fisika di SMA N 1 Waway Karya Bandar Lampung Timur terdapat masalah pada saat pembelajaran berlangsung, peserta didik cenderung pasif dan tidak memperhatikan materi yang dijelaskan oleh guru. Masalah tersebut terjadi karena pembelajaran yang berpusat pada guru. Hal ini menunjukkan bahwa kemampuan berpikir kritis siswa sangat rendah.

Kemampuan berpikir kritis ini dapat dikembangkan dengan model pembelajaran yang mengandung beberapa proses, yaitu penguasaan materi, internalisasi dan transfer materi pada kasus yang berbeda. Model pembelajaran yang memenuhi kriteria tersebut adalah model problem-based learning dan model pembelajaran inkuiri terbimbing (Diani et al, 2016). Rata-rata 
tingkat kemampuan berpikir kritis peserta didik dengan Problem Based Learning termasuk kategori "berkembang", artinya model ini berguna untuk menunjang kemampuan berpikir kritis peserta didik karena dapat mengubah peserta didik dari penerima informasi pasif menjadi aktif, mandiri dan pemecah masalah (Furlog et al., 2003). Pengembangan kemampuan berpikir kritis sering dijadikan sebagai alasan yang paling penting untuk pendidikan formal karena model tersebut sangat penting bagi keberhasilan dalam dunia pendidikan di mana tingkat pengetahuan baru dibuat secara cepat. (Marin \& Diane, 2011).

\section{Model Problem Based Learning} merupakan model pembelajaran yang memberikan suatu masalah yang terkait dengan kehidupan sehari-hari sebagai langkah awal pembelajaran dan guru membimbing siswa untuk menemukan solusi dari permasalahan melalui kemampuan berpikir kritis dan pemecahan masalah(Diani et al., 2016). Dalam (Ritonga et al., 2020) menyebutkan bahwa pembelajaran berbasis masalah dapat membatu untuk meningkatkan keterampilan belajar sepanjang hayat dalam pola pikir yang terbuka, reflektif, kritis dan belajar aktif. Tujuan utama dari model PBL adalah pengembangan kemampuan berpikir kritis dan kemampuan pemecahan masalah, sekaligus mengembangkan kemampuan peserta didik secara aktif membangun pengetahuannya sendiri.

Dalam PBL siswa dituntun untuk memecahkan, menganalisis serta mengevaluasi sebuah permasalahan. Siswa akan terlibat langsung dalam upaya memecahkan masalah dengan menggunakan kemampuan berpikir, pengalaman dan konsep-konsep yang akan ditemukan pada pemecahan masalah yang disajikan. Selain itu siswa dilatih untuk berusaha berpikir kritis dan mampu mengembangkan kemampuan analisisnya serta menjadi pembelajar yang mandiri. PBL melibatkan peserta didik untuk memecahkan masalah dunia nyata melalui tahap-tahap tertentu sehingga peserta didik dapat mempelajari pengetahuan yang berhubungan dengan masalah tersebut dan sekaligus memiliki keterampilan untuk memecahkan masalah (Qomariyah, 2016)

Uraian permasalahan tersebut mendorong peneliti untuk melakukan penelitian terkait dengan pengaruh model pembelajaran problem-based learning terhadap kemampuan berpikir kritis siswa. Penelitian ini dilakukan dengan beberapa tujuan yaitu menganalisis pengaruh yang diberikan oleh model problem-based learning terhadap kemampuan berpikir kritis siswa, menganalisis besarnya pengaruh yang diberikan oleh model problem-based learning terhadap kemampuan berpikir kritis siswa berdasarkan tingkat pendidikan, materi yang diajarkan, dan tingkatan kelas.

\section{METODE PENELITIAN}

Penelitian ini menggunakan metode penelitian meta analisis yang mana penelitian ini bersifat kuantitatif karena menggunakan perhitungan angka dan statistik dimana meta-analysis adalah kajian atas sejumlah hasil penelitian pada masalah yang sama pengumpulan data dilakukan dengan cara menelusuri Google Scholar atau Google Cendekia dengan mengkaji beberapa artikel pada jurnal nasional kata kunci yang digunakan dalam pencernaan ini adalah pengaruh pengembangan problem based learning kemampuan berpikir kritis siswa SMA. meta-analisis ini bersifat kuantitatif karena menggunakan perhitungan angka dan statistik penelitian meta analisis ini menggunakan 20 sampel jurnal yang relevan pada jurnal nasional.

Artikel meta analisis ini menggunakan pengkodean (coding) untuk mempermudah pengumpulan data. Pengkodean yang 
dilakukan yaitu dengan mengganti nama artikel-artikel yang akan di analisis dengan kode A1 sampai A20.

Langkah langkah penelitian metaanalisis menurut David B. Wilson dan George A. Kelley dalam (Anggreni et al., 2019), yaitu:

a. Menetapkan masalah atau topic yang diteliti. Masalah dan topik yang diteliti dalam penelitian ini adalah pengaruh model problem-based learning terhadap kemampuan berpikir kritis siswa.

b. Menentukan periode penelitian penelitian terdahulu yang dijadikan sumber data.

c. Mencari laporan penelitian dari berbagai sumber yang relevan dengan topik yang ingin diteliti.

d. Membaca judul dan abstrak dari jurnal pendidikan dan melihat kecocokan isinya dengan topik yang ingin diteliti.

e. Memfokuskan penelitian pada masalah, metodelogi penelitian seperti jenis penelitian seperti jenis penelitian, tempat dan waktu penelitian, metode, populasi, sampel, teknik penarikan sampel, teknik analisis data dan hasi.

f. Mengkategorikan masing - masing penelitian.

g. Menganalisis kesimpulan yang ditemukan.

Tabel 1. Distribusi sampel penelitian untuk berpikir kritis siswa berdasarkan jenjang pendidikan

\begin{tabular}{lll}
\hline No & Jenjang Pendidikan & Jumlah Penelitian \\
\hline 1. & SMP & 3 \\
\hline 2. & SMA & 17 \\
\hline
\end{tabular}

Tabel 2. Distribusi sampel penelitian untuk berpikir kritis siswa berdasarkan tingkatan kelas

\begin{tabular}{lll}
\hline No & Tingkatan kelas & Jumlah Penelitian \\
\hline 1. & VII & 1 \\
\hline 2. & VIII & 2 \\
\hline
\end{tabular}

\begin{tabular}{lll}
\hline No & Tingkatan kelas & Jumlah Penelitian \\
\hline 3. & X & 7 \\
\hline 4. & XI & 10 \\
\hline
\end{tabular}

Tabel 3. Distribusi sampel penelitian untuk berpikir kritis siswa berdasarkan Materi pembelajaran

\begin{tabular}{lll}
\hline No & Materi & Jumlah Penelitian \\
\hline 1. & Usaha dan energi & 3 \\
\hline 2. & Fluida & 2 \\
\hline 3. & Tekanan zat & 1 \\
\hline 4. & Gerak & 2 \\
\hline 5. & Elastisitas & 1 \\
\hline 6. & Getaran harmonik & 1 \\
\hline 7. & Arus listrik dan & 1 \\
& hambatan listrik \\
\hline 8. & Suhu dan kalor & 1 \\
\hline
\end{tabular}

Tabel diatas menjabarkan sampelsampel penelitian tentang pengaruh model problem based learning terhadap kemampuan berfikir kritis siswa. Sampel yang digunakan berjumlah 20 artikel, yang dikelompokkan berdasarkan jenjang pendidikan, tingkatan kelas dan materi pelajaran. Pengelompokan artikel berdasarkan jenjang pendidikan yaitu 3 artikel pada jenjang SMP dan 17 artikel pada jenjang SMA. Pengelompokan artikel berdasarkan tingkatan kelas yaitu kelas VII (1 artikel), kelas VIII (2 artikel), kelas X (7 artikel) dan kelas XI (10 artikel). Sedangkan pengelompokan artikel berdasarkan materi yaitu materi usaha dan energi, fluida, gerak, tekanan zat, elastisitas, getaran harmonik, arus listrik dan hambatan listrik, serta suhu dan kalor.

Dikarenakan artikel yang digunakan menggunakan analisis data yang berbeda sehingga diperlukan rumus-rumus turunan effect size. 


\begin{tabular}{|c|c|c|c|}
\hline No & Jenis Uji & Rumus & Ket \\
\hline 1. & Uji Z & $E S=Z \sqrt{\frac{1}{n e}}+\frac{1}{n c}$ & $\begin{array}{l}\text { Keterangan : } \\
\mathrm{Z} \text { : skor dari nilai uji-z pada penelitian mula-mula } \\
\text { ne : banyaknya sampel kelompok eksperimen } \\
\text { nc : banyaknya sampel kelompok kontrol }\end{array}$ \\
\hline 2. & Uji -t & $\begin{array}{l}E S=\sqrt{\frac{2 t}{n}} \text { dan } E S \\
=Z \sqrt{\frac{1}{n e}+\frac{1}{n c}}\end{array}$ & $\begin{array}{l}\text { Keterangan: } \\
t: \text { skor dari nilai test-t pada penelitian mula-mula } \\
n: \text { banyaknya sampel } \\
n_{e}: \text { banyaknya sampel kelompok eksperimen }\end{array}$ \\
\hline 3. & $\begin{array}{l}\text { Korelasi } \\
(\mathrm{Uji}-r)\end{array}$ & $\begin{array}{l}E S=\frac{\left\{2_{r}\right\}}{\{\sqrt{(1-r)}\}} \\
\text { (Sutrisno, Kresnadi, } \\
\text { dan Kartono, 2007:4- } \\
\text { 10) }\end{array}$ & $\begin{aligned} r: & \text { skor dari uji-r pada penelitia mula-mula } \\
& \quad \text { (Sutrisno, Kresnadi, dan Kartono, 2007:4-10) }\end{aligned}$ \\
\hline 4. & Uji F & $E S=F \sqrt{\frac{2}{n}}$ & $\begin{array}{l}\text { Keterangan: } \\
F: \text { skor dari uji-f pada penelitian mula-mula } \\
n: \text { jumlah sampel }\end{array}$ \\
\hline 5. & $\mathrm{Uji}-X^{2}$ & $E S=\frac{\sqrt{X^{2}}}{n}$ & $\begin{array}{l}\text { Keterangan: } \\
X^{2}: \text { skor dari uji- } x^{2} \text { pada penelitian mula-mula } \\
n: \text { jumlah sampel } \\
\text { (Wilkinson, and APA Task Force on statistical Inference, } \\
1999 \text { ) }\end{array}$ \\
\hline
\end{tabular}

Untuk mencari nilai effect size digunakanteknik analisis data menggunakan persamaan berikut.

ES

post test average score-pre test average score SD kontrol

(Rumus ES untuk satu kelompok sampel)

Atau

ES

eksperimen average score-kontrol average score SD kontrol

(Rumus ES untuk dua kelompok sampel)

Keterangan :

ES = Effect size

Post test average score $=$ Posttest mean

Pre test average score $=$ Pretest mean

$\mathrm{SD}=$ Standard deviation

$=$
Dengan kriteria ukuran effek Size (Glass, 1981)

-effect size $\leq 0,15$ efek yang dapat diabaikan

- $0,15<$ effect size $\leq 0,40$ efek rendah

$-0,40<$ effect size $\leq 0,75$ efek sedang

$\bullet 0,75<$ effect size $\leq 1.10$ efek tinggi

- $1.10<$ effect size $\leq 1,45$ efek yang sangat tinggi

- $1,45<$ effect size pengaruh yang tinggi

\section{HASIL DAN PEMBAHASAN Hasil}

Artikel pertama sampai artikel dua puluh dilambangkan dengan pemberian kode (code category) dengan A1 sampai A20, yang mana artikel A1-A20 merupakan artikel national. Distribusi penyebaran pengaruh model problem-based Learning 
terhadap kemampuan berfikir kritis siswa.

dapat dilihat pada Tabel 1 berikut ini.

Tabel 1. Distribusi Penyebaran Data Pengaruh Model Problem Based Learning Terhadap Kemampuan Berpikir Kritis Siswa

\begin{tabular}{|c|c|c|c|c|c|c|c|}
\hline No & $\begin{array}{c}\text { Sumber } \\
\text { Artikel }\end{array}$ & $\begin{array}{c}\text { Kode } \\
\text { Artikel }\end{array}$ & $\begin{array}{c}\text { Jenjang } \\
\text { Pendidikan }\end{array}$ & Kelas & $\begin{array}{l}\text { Effect } \\
\text { Size }\end{array}$ & Kategori & $\begin{array}{l}\text { Rata-Rata } \\
\text { Effect Size }\end{array}$ \\
\hline 1. & $\begin{array}{l}\text { ( Yulianti } \\
\text { \&Gunawan } \\
\text { dkk,2019) }\end{array}$ & A1 & SMP & VII & 0,15 & Rendah & \multirow{17}{*}{2.25} \\
\hline 2. & $\begin{array}{c}\text { (Munandar } \\
\text { et al } \\
\text { dkk,2018) }\end{array}$ & $\mathrm{A} 2$ & SMP & VIII & 3,14 & $\begin{array}{l}\text { Sangat } \\
\text { Tinggi }\end{array}$ & \\
\hline 3. & $\begin{array}{c}\text { (Sunariyati } \\
\text { et al } \\
\text { dkk,2014) }\end{array}$ & A3 & SMP & VIII & 0,59 & Sedang & \\
\hline 4. & $\begin{array}{c}\text { (Nasihah et } \\
\text { al } \\
\text { dkk,2019) }\end{array}$ & A4 & SMA & $\begin{array}{c}\text { X- } \\
\text { MIP } \\
\text { A }\end{array}$ & 1,86 & $\begin{array}{l}\text { Sangat } \\
\text { tinggi }\end{array}$ & \\
\hline 5. & $\begin{array}{c}\text { (Islamiah et } \\
\text { al } \\
\mathrm{dkk}, 2018)\end{array}$ & A5 & SMA & $\begin{array}{c}\text { X- } \\
\text { MIA }\end{array}$ & 1,11 & $\begin{array}{l}\text { Sangat } \\
\text { Tinggi }\end{array}$ & \\
\hline 6. & $\begin{array}{c}\text { (Lehan et al } \\
\text { dkk,2018) }\end{array}$ & A6 & SMA & $\begin{array}{l}\text { XI- } \\
\text { MIA }\end{array}$ & 0,86 & Tinggi & \\
\hline 7. & $\begin{array}{l}\text { (Hasibuan } \\
\text { et al, } \\
\text { dkk,2018) }\end{array}$ & A7 & SMA & $\begin{array}{l}\text { XI- } \\
\text { IPA }\end{array}$ & 0,54 & Sedang & \\
\hline 8. & $\begin{array}{c}\text { (Santoso et } \\
\text { al } \\
\text { dkk,2016) }\end{array}$ & A8 & SMA & $\begin{array}{c}\text { X- } \\
\text { MIP } \\
\text { A }\end{array}$ & 0,50 & Sedang & \\
\hline 9. & $\begin{array}{c}\text { (Wulandari } \\
\text { et al } \\
\text { dkk,2020) }\end{array}$ & A9 & MAN & $\begin{array}{c}\text { X- } \\
\text { MIP } \\
\text { A }\end{array}$ & 0,44 & Sedang & \\
\hline 10. & $\begin{array}{l}\text { (Ramadhani } \\
\text { \&Murtiani } \\
\text { dkk2019) }\end{array}$ & A10 & MA & $\begin{array}{c}\text { X- } \\
\text { MIP } \\
\text { A }\end{array}$ & 2,81 & $\begin{array}{l}\text { Sangat } \\
\text { Tinggi }\end{array}$ & \\
\hline 11. & $\begin{array}{c}\text { (Rahmad et } \\
\text { al } \\
\text { dkk,2016) }\end{array}$ & A11 & SMA & $\begin{array}{c}\text { XI- } \\
\text { MIP } \\
\text { A }\end{array}$ & 1,01 & Tinggi & \\
\hline 12. & $\begin{array}{c}\text { (Putri. R } \\
\text { dkk,2016) }\end{array}$ & A12 & SMA & $\begin{array}{l}\text { XI- } \\
\text { IPA }\end{array}$ & 1,13 & $\begin{array}{l}\text { Sangat } \\
\text { tinggi }\end{array}$ & \\
\hline 13. & $\begin{array}{c}\text { (Paradina et } \\
\text { al } \\
\mathrm{dkk}, 2019)\end{array}$ & A13 & SMA & $\begin{array}{c}\mathrm{X}- \\
\mathrm{MIP} \\
\mathrm{A}\end{array}$ & 1,05 & Tinggi & \\
\hline 14. & $\begin{array}{l}\text { (Aulia et al } \\
\text { dkk,2019) }\end{array}$ & A14 & SMA & $\begin{array}{c}\text { XI- } \\
\text { IPAA }\end{array}$ & 5,09 & $\begin{array}{l}\text { Sangat } \\
\text { Tinggi }\end{array}$ & \\
\hline 15. & $\begin{array}{l}\text { (Purwanto } \\
\text { dkk,2018) }\end{array}$ & A15 & SMA & $\begin{array}{l}\text { XI- } \\
\text { IPA }\end{array}$ & 4,83 & $\begin{array}{l}\text { Sangat } \\
\text { tinggi }\end{array}$ & \\
\hline 16. & $\begin{array}{l}\text { (Pepo et al } \\
\text { dkk,2019) }\end{array}$ & A16 & SMA & $\begin{array}{l}\text { XI- } \\
\text { IPA }\end{array}$ & 0,42 & Sedang & \\
\hline 17. & $\begin{array}{c}\text { (Sitanggang } \\
\text { \&Sari } \\
\text { Wahyuni }\end{array}$ & A17 & SMA & $\begin{array}{l}\text { XI- } \\
\text { IPA }\end{array}$ & 1,69 & $\begin{array}{l}\text { Sangat } \\
\text { Tinggi }\end{array}$ & \\
\hline
\end{tabular}




\begin{tabular}{|c|c|c|c|c|c|c|c|}
\hline No & $\begin{array}{c}\text { Sumber } \\
\text { Artikel }\end{array}$ & $\begin{array}{c}\text { Kode } \\
\text { Artikel }\end{array}$ & $\begin{array}{c}\text { Jenjang } \\
\text { Pendidikan }\end{array}$ & Kelas & $\begin{array}{c}\text { Effect } \\
\text { Size }\end{array}$ & Kategori & $\begin{array}{l}\text { Rata-Rata } \\
\text { Effect Size }\end{array}$ \\
\hline & $\begin{array}{c}\text { Rozi } \\
\text { Nasution } \\
\text { dkk,2018) }\end{array}$ & & & & & & \\
\hline 18. & $\begin{array}{c}\text { (Sugrah et } \\
\text { al } \\
\text { dkk,2017) }\end{array}$ & A18 & SMA & $\begin{array}{c}\text { XI- } \\
\text { MIP } \\
\text { A }\end{array}$ & 1,49 & $\begin{array}{c}\text { Sangat } \\
\text { tinggi }\end{array}$ & \\
\hline 19. & $\begin{array}{c}\text { (Redgana } \\
\text { dkk,2013) }\end{array}$ & A19 & SMA & $\begin{array}{l}\text { XI- } \\
\text { IPA }\end{array}$ & 0,89 & tinggi & \\
\hline 20. & $\begin{array}{c}\text { (Kurniati et } \\
\text { al } \\
\text { dkk,2019) }\end{array}$ & A20 & SMA & $\begin{array}{l}\text { XI- } \\
\text { IPA }\end{array}$ & 15,7 & $\begin{array}{l}\text { Sangat } \\
\text { Tinggi }\end{array}$ & \\
\hline
\end{tabular}

Nilai rata-rata effect size berdasarkan tingkatan jenjang Pendidikan dari 20 artikel pada jurnal nasional dapat dilihat pada Tabel 2.

Tabel 2. Effect Size Berdasarkan Tingkatan JenjangPendidikan

\begin{tabular}{|l|l|l|l|l|}
\hline $\begin{array}{l}\mathrm{N} \\
\mathrm{o}\end{array}$ & $\begin{array}{l}\text { Jenjang } \\
\text { Pendidika } \\
\mathrm{n}\end{array}$ & $\begin{array}{l}\text { Jumlah } \\
\text { Penelitia } \\
\mathrm{n}\end{array}$ & $\begin{array}{l}\text { Effec } \\
t \text { Size }\end{array}$ & $\begin{array}{l}\text { Kategor } \\
\mathrm{i}\end{array}$ \\
\hline 1. & SMP & 3 & 1,29 & $\begin{array}{l}\text { Sangat } \\
\text { tinggi }\end{array}$ \\
\hline 2. & SMA & 17 & 2,43 & $\begin{array}{l}\text { Sangat } \\
\text { tinggi }\end{array}$ \\
\hline
\end{tabular}

Nilai effect size berdasarkan tingkatan kelas dari 20 artikel jurnal nasional yang digunakan dapat dilihat pada tabel 3 .

Tabel 3. Effect Size berdasarkan tingkatan kelas

\begin{tabular}{|l|l|l|l|l|}
\hline No & $\begin{array}{l}\text { Tingkata } \\
\text { n kelas }\end{array}$ & $\begin{array}{l}\text { Jumlah } \\
\text { Penelitia } \\
\mathrm{n}\end{array}$ & $\begin{array}{l}\text { Effec } \\
\mathrm{t} \text { Size }\end{array}$ & $\begin{array}{l}\text { kategor } \\
\mathrm{i}\end{array}$ \\
\hline 1. & VII & 1 & 0,15 & Rendah \\
\hline 2. & VIII & 2 & 1,86 & $\begin{array}{l}\text { Sangat } \\
\text { tinggi }\end{array}$ \\
\hline 3. & $\mathrm{X}$ & 7 & 1,16 & $\begin{array}{l}\text { Sangat } \\
\text { tinggi }\end{array}$ \\
\hline 4. & XI & 10 & 3,33 & $\begin{array}{l}\text { Sangat } \\
\text { tinggi }\end{array}$ \\
\hline
\end{tabular}

Nilai effect size berdasarkan materi pembelajaran dari 20 artikel yang terdiri dari artikel jurnal nasional dapat dilihat pada Tabel 4.
Tabel 4. Effect Size Berdasarkan Materi

\begin{tabular}{|c|c|c|c|c|}
\hline \multicolumn{5}{|c|}{ Pembelajaran } \\
\hline $\begin{array}{l}\mathrm{N} \\
\mathrm{o}\end{array}$ & Materi & $\begin{array}{l}\text { Jumlah } \\
\text { Penelitia } \\
\mathrm{n}\end{array}$ & $\begin{array}{l}\text { Effec } \\
\text { t Size }\end{array}$ & $\begin{array}{l}\text { kategor } \\
\text { i }\end{array}$ \\
\hline 1. & $\begin{array}{l}\text { Usaha } \\
\text { dan } \\
\text { energi }\end{array}$ & 3 & 2,29 & $\begin{array}{l}\text { Sangat } \\
\text { tinggi }\end{array}$ \\
\hline 2. & Fluida & 2 & 2,99 & $\begin{array}{l}\text { Sangat } \\
\text { tinggi }\end{array}$ \\
\hline 3. & $\begin{array}{l}\text { Tekanan } \\
\text { zat }\end{array}$ & 1 & 0,59 & Sedang \\
\hline 4. & Gerak & 2 & 0,82 & Tinggi \\
\hline 5. & $\begin{array}{l}\text { Elastisita } \\
\mathrm{s}\end{array}$ & 1 & 1,69 & $\begin{array}{l}\text { Sangat } \\
\text { tinggi }\end{array}$ \\
\hline 6. & $\begin{array}{l}\text { Getaran } \\
\text { harmonik }\end{array}$ & 1 & 0,50 & Sedang \\
\hline 7. & $\begin{array}{l}\text { Arus } \\
\text { listrik dan } \\
\text { hambatan } \\
\text { listrik }\end{array}$ & 1 & 2,81 & $\begin{array}{l}\text { Sangat } \\
\text { tinggi }\end{array}$ \\
\hline 8. & $\begin{array}{l}\text { Suhu dan } \\
\text { kalor }\end{array}$ & 1 & 1,86 & $\begin{array}{l}\text { Sangat } \\
\text { tinggi }\end{array}$ \\
\hline
\end{tabular}

\section{Pembahasan}

Berdasarkan hasil penelitian yang dilakukan, yaitu: pengaruh problem based learning terhadap kemampuan berfikir kritis siswa ditinjau dari jenjang pendidikan dan materi pembelajaran fisika.

Secara umum, artikel- artikel yang telah dianalisis memiliki nilai effect size dengan kategori sangat tinggi. Untuk effect size dengan kategori sangat tinggi memiliki persentase $50 \%$ dari keseluruhan artikel, sedangkan effect size dengan kategori tinggi memiliki persentase $20 \%$. Untuk artikel 
dengan kategori effect size sedang memiliki persentase $25 \%$ dan artikel dengan kategori effect size rendah memiliki persentase $5 \%$. Berdasarkan data tersebut, dapat kita ketahui bahwa model pembelajaran problem based learning ini mempunyai dampak yang sangat tinggi terhadap kemampuan berpikir kritis siswa.

Berdasarkan Tabel 1 dapat dilihat bahwa model problem based learning memberikan pengaruh positif yang tinggi terhadap kemampuan berpikir kritis siswa. Terlihat pada tabel diatas, rata-rata effect size untuk model pembelajaran problem based learning terhadap kemampuan berpikir kritis siswa adalah 2,25 dengan kategori sangat tinggi dengan persentase mencapai $50 \%$. Hal ini sejalan dengan yang dikemukakan oleh Yosiwita dkk (2013) yang menyatakan bahwa hasil berpikir kritis mengalami peningkatan sebesar $32,57 \%$ dengan menggunakan model pembelajaran Problem Based Learning. Pernyataan yang sama juga dikemukakan oleh Ayuningrum (2015), pembelajaran menggunakan model Problem Based Learning pada kelas eksperimen mengalami peningkatan kemampuan berpikir kritis siswa lebih besar dibandingkan dengan kelas kontrol.

Berdasarkan Tabel 2 menunjukkan bahwa hasil meta-analisis pengaruh model problem based learning terhadap kemampuan berpikir krtis siswa memberikan pengaruh yang positif, terlihat dari besarnya effect size yang dikategorikan sangat tinggi terhadap kemampuan berpikir kritis siswa pada jenjang pendidikan SMA maupun SMP. Effect size pada jenjang pendidikan SMA bernilai 2,43 dan pada jenjang pendidikan SMP bernilai 1,29. Berdasarkan data effect size tersebut, dapat diketahui bahwa nilai effect size pada jenjang pendidikan SMA lebih besar dibandingkan pada jenjang SMP. Hal ini menunjukkan bahwa model problem based learning terhadap kemampuan berfikir kritis siswa akan semakin efektif digunakan pada jenjang Pendidikan SMA. Hal ini sejalan dengan penelitian yang dilakukan oleh (Qomariah et al., 2015) terhadap siswa kelas VII SMP Negeri 19 Mataram Tahun Pelajaran 2014/2015, bahwa kelas eksperimen dengan model problem based learning dengan metode eksperimen menunjukkan peningkatan hasil belajar IPA fisika yang lebih tinggi dibandingkan kelas kontrol dengan model pembelajaran konvensional. Penelitian lain yang dilakukan oleh Adnyana (2008) juga menunjukkan bahwa pelaksanaan pembelajaran dengan model Problem Based Learning dapat meningkatkan kemampuan berpikir kritis siswa kelas X-5 SMA Negeri 1 Banjar yang ditandai dengan adanya keterampilan merumuskan masalah, memberikan argumentasi, melakukan induksi, dan memberikan penilaian.

Hasil meta-analisis pengaruh model problem based learning terhadap kemampuan berfikir kritis siswa berdasarkan tingkatan kelas dapat dilihat pada Tabel 3. Secara keseluruhan, nilai effect size pengaruh problem based learning terhadap kemampuan berpikir kritis siswa berdasarkan tingkatan kelas memiliki kategori sangat tinggi, dari 4 tingkatan kelas yang ada yaitu kelas VII, VIII, X dan XI. Persentase nilai effect size pengaruh model problem based learning terhadap kemampuan berpikir kritis siswa berdasarkan tingkatan kelas dengan kategori tinggi adalah 75\%. Dari 20 artikel yang telah di analisis, 10 di antaranya membahas mengenai pengaruh model problem based learning terhadap kemampuan berpikir kritis siswa pada tingkatan kelas XI. Dibandingkan dengan tingkatan kelas lain, effect size pada tingkatan kelas XI adalah yang paling besar yaitu 3,33 dengan kategori sangat tinggi. Sedangkan nilai effect size 
yang paling kecil terdapat pada tingkatan kelas VII, yaitu 0,15 yang dikategorikan rendah. Artinya model pembelajaran problem based learning lebih cocok digunakan pada kelas XI karena dibandingkan tingkatan kelas lain, model problem based learning di kelas XI memiliki pengaruh yang lebih besar dalam meningkatkan kemampuan berpikir kritis siswa.

Berdasarkan Tabel 4 dapat dilihat pengaruh model problem based learning terhadap kemampuan berpikir kritis siswa berdasarkan materi pembelajaran, hasil meta-analisis menunjukkan bahwa didapat pengaruh yang tertinggi penggunaan model problem based learning terhadap kemampuan berfikir kritis siswa terdapat pada materi fluida. Besar nilai effect size yang didapat yaitu 2,99 yang dikategorikan sangat tinggi. Sedangkan nilai effect size yang paling kecil terdapat pada materi getaran harmonik dengan nilai effect size sebesar 0,5 dengan kategori sedang.

Model pembelajaran problem based learning memberikan pengaruh yang positif terhadap materi-materi pelajaran fisika, dimana rentang kategori nilai effect size nya adalah 0,5 (kategori sedang) hingga 2,99 (sangat tinggi). Hal ini sejalan dengan yang dinyatakan oleh (Riyadi et al., 2015) bahwa penerapan model problem based learning dapat memberi efek positif terhadap kemampuan berpikir kritis dan hasil belajar fisika.

\section{PENUTUP}

Berdasarkan hasil meta-analisis, dapat disimpulkan bahwa model problem-based learning) memberikan pengaruh yang tinggi terhadap keterampilan berpikir kritis siswa $(2,25)$. Berdasarkan tingkatan jenjang pendidikan model ini lebih efektif digunakan pada tingkatan SMA $(2,43)$, berdasarkan materi pembelajaran pengaruh model problem based learning sangat tinggi pada materi fluida $(2,99)$, berdasarkan tingkatan kelas model problem based learning berpengaruh pada tingkatakan kelas XI SMA $(3,33)$.

\section{REFERENSI}

Adnyana, G. P. (2008). Meningkatkan Kualitas Aktivitas Belajar, Keterampilan Berpikir Kritis, dan Pemahaman Konsep Biologi Kelas X5 SMA Negeri 1 Banjar Melalui Penerapan Model Pembelajaran Berbasis Masalah. Singaraja: Undiksha.

Anggreni, Y. D., Festiyed, \& Asrizal. (2019). Meta-Analisis Pengaruh Model Pembelajaran Project Based Learning Terhadap Kemampuan Berpikir Kritis Peserta Didik SMA Program Studi Magister Pendidikan Fisika. Pillar of Physics Education, 12(4), 881-888.

Al-Fikry, I., Yusrizal, Y., \& Syukri, M. (2018). Pengaruh model problembased learning terhadap kemampuan berpikir kritis peserta didik pada materi kalor. Jurnal Pendidikan Sains Indonesia (Indonesian Journal of Science Education), 6(1), 17-23.

Aulia, Z., Ulfah, M., \& Firmansyah, A. (2019). Pengaruh Model Pembelajaran Berbasis Masalah terhadap Kemampuan Berpikir Kritis Siswa. JKPM (Jurnal Kajian Pendidikan Matematika), 4(1), 11. https://doi.org/10.30998/jkpm.v4i1.30 25

Ayuninggrum, Diah dan Sri Muliyani Endang Susilowati. 2015. Pengaruh Model

Problem Based Learning terhadap Keterampilan Berpikir Kritis Siswa SMA Pada Materi Protista. Jurusan Biologi,FMIPA, Universitas Negeri Semarang,

Indonesia. Jurnal tidak diterbitkan (online).

http://journal.unnes.ac.id/sju/index.ph 
p/ujbe, diakses 23 Juni 2021.

Diani, R., Saregar, A., \& Ifana, A. (2016). Perbandingan Model Pembelajaran Problem Based Learning dan Inkuiri Terbimbing Terhadap Kemampuan Berpikir Kritis Peserta Didik. Jurnal Penelitian Pembelajaran Fisika, 7(2).

Furlog, M.J., Whipple, A.D., Jean,S.G., Simental, J., Soliz, A., \& Punthuna, S. (2003). Multiple cotexts of school engagement: moving toward a unifying framework for educational research and practice. The California School Phychologist, 9:99-114.

Glass, G.V., McGaw B., \& Smith, M.L. (1981). Meta-Analysis in Social Research. Sage Publications. London: Sage Publications

Hasibuan, L., Hutabarat, H. D., Siregar, N., Program, M., Pendidikan, S., Universitas, F., \& Nusantara, G. (2021). PENGARUH MODEL PEMBELAJARAN PROBLEM BASED LEARNING ( PBL ) TERHADAP KEMAMPUAN BERPIKIR KRITIS SISWA KELAS XI PADA POKOK BAHASAN FLUIDA DI SMA NEGERI 2 SIABU. 5(1).

Hasyda, S., \& Arifin, A. (2020). Penerapan Model Problem Based Learning Untuk Meningkatkan Kemampuan Berpikir Kritis Siswa Kelas IV Di Sekolah Dasar. PENDAS MAHAKAM: Jurnal Pendidikan Dasar, 5(1), 62-69.

Islamiah, A. F., Rahayu, S., \& Verawati, N. N. S. P. (2018). Efektivitas Model Pembelajaran Problem Based Learning Berbantuan LKS Terhadap Kemampuan Berpikir Kritis Fisika Siswa SMAN 1 Lingsar Tahun Ajaran 2016/2017. Lensa: Jurnal Kependidikan Fisika, 6(1), 29. https://doi.org/10.33394/j-

lkf.v6i1.933

Kurniati, D., Khairil, K., \& Darwin, C. (2019). Kemampuan Berpikir Kritis Siswa pada Pembelajaran PBL dengan Media Audio Visual di SMP Negeri 6 Bengkulu Tengah. Seminar Nasional
Sains $\quad$..., 2014, 1-7.

http://conference.upgris.ac.id/index.p $\mathrm{hp} / \mathrm{snse} / \mathrm{article} / \mathrm{view} / 254$

Lehan, F. E., Elizabeth, A., \& Dua, Y. S. (2018). Pengaruh Model Pembelajaram Problem Based Learning Terhadap Kemampuan Berpikir Kritis Siswa Pada Materi Usaha Dan Energi Di SMA Negeri 2 Maumere Tahun Ajaran 2017/2018.

Marin, L.M.\&Diane, F.H. 2011. Pedagogy for developing critical thinking in adolescents: Explicit instruction produces greatest gains. Thingking Skills and Creativity, 6:1-13.

Munandar, H., Sutrio, S., \& Taufik, M. (2018). Pengaruh Model Pembelajaran Berbasis Masalah Berbantuan Media Animasi Terhadap Kemampuan Berpikir Kritis dan Hasil Belajar Fisika Siswa SMAN 5 Mataram Tahun Ajaran 2016/2017. Jurnal Pendidikan Fisika Dan Teknologi, 4(1), 111. https://doi.org/10.29303/jpft.v4i1.526

Nasihah, E. D., Supeno, S., \& Lesmono, A. D. (2020). Pengaruh Tutor Sebaya Dalam Pembelajaran Problem Based Learning Terhadap Keterampilan Berpikir Kritis Fisika Siswa Sma. Jurnal Pendidikan Fisika, 8(1), 44. https://doi.org/10.24127/jpf.v8i1.1899

Nurqomariah, N., Gunawan, G., \& Sutrio, S. (2017). Pengaruh Model Problem Based Learning dengan Metode Eksperimen Terhadap Hasil Belajar IPA Fisika Siswa Kelas VII SMP Negeri 19 Mataram Tahun Pelajaran 2014/2015. Jurnal Pendidikan Fisika dan Teknologi, 1(3), 173-179.

Paradina, D., Connie, C., \& Medriati, R. (2019). Pengaruh Model Pembelajaran Problem Based Learning Terhadap Hasil Belajar Siswa Di Kelas X. Jurnal Kumparan Fisika, 2(3), 169176.

https://doi.org/10.33369/jkf.2.3.169$\underline{176}$

Pepo, A. R. R., Arjaya, I. B. A., \& Paraniti, A. A. I. (2019). Penerapan Model 
Pembelajaran Problem Based Learning Berbasis Googleclassroom Terhadap Kemampuan Berpikir Kritis Ditinjau Dari Gaya Kognitif Siswa. Jurnal Biologi Kontekstual, 1(2), 2656-9043. https://ejournal.unmas.ac.id/index.php/JBK/ar ticle/view/628

Purwanto, R. (2018). Pengaruh Model Pembelajaran Project Based Learning terhadap Kemampuan Berpikir Kreatif Siswa. PRISMATIKA: Jurnal Pendidikan Dan Riset Matematika, 1(1), 1-9. https://doi.org/10.33503/prismatika.v $\underline{1 i 1.291}$

Putri, R. (2016). Pengaruh Model Problem Based Learning Terhadap Berpikir Kritis Dan Hasil Belajar Elastisitas Siswa Kelas Xi Sma Negeri 7 Banda Aceh. Jurnal Pendidikan Sains Indonesia, $\quad 4(1), \quad 122494$. https://doi.org/10.24815/jpsi.v4i1.658 $\underline{9}$

Qomariyah, E. N. (2017). Pengaruh Problem Based Learning terhadap Kemampuan Berpikir Kritis IPS. Jurnal Pendidikan dan Pembelajaran (JPP), 23(2), 132141.

Rahmat, S. A., Pasaribu, M., \& Darmadi, I. W. (2016). Pengaruh Pembelajaran Berbasis Masalah Terhadap Keterampilan Berpikir Kritis Siswa Pada Materi Gerak di Kelas X SMA Negeri 6 Sigi. JPFT (Jurnal Pendidikan Fisika Tadulako Online), 4(3),

https://doi.org/10.22487/j25805924.2 $\underline{016 . v 4.13 .6213}$

Ramadani, I., \& Murtiani. (2019). Pengaruh Implementasi Problem Based Learning (PBL) Terhadap Keterampilan Berpikir Kritis Siswa Dalam Pembelajaran Fisika. ISSN 2502-3632 (Online) ISSN 2356-0304 (Paper) Jurnal Online Internasional \& Nasional Vol. 7 No.1, Januari - Juni 2019 Universitas 17 Agustus 1945 Jakarta, 53(9), 1689-1699. www.journal.uta45jakarta.ac.id
Redhana, I. W. (2013). Model Pembelajaran Berbasis Masalah Dan Pertanyaan Socratik Untuk Meningkatkan Keterampilan Berpikir Kritis Siswa. Jurnal Cakrawala Pendidikan, 3, 351-365.

https://doi.org/10.21831/cp.v0i3.1136

Ritonga, N., Gultom, H. S. B., \& Nazliah, R. (2020). Kemampuan Berpikir Kritis Dalam Proses Pembelajaran IPA Melalui Pendekatan Keterampilan. JURNAL

PENDIDIKAN SAINS DAN
APLIKASINYA, 3(2), 41-45.

Riyadi, P.M.S., Pujani, N.M., \& Suswandi, I. 2015. Penerapan Model Pembelajaran Berbasis

Masalah untuk Meningkatkan Keterampilan Berpikir Kritis dan Hasil Belajar Fisika Siswa. Jurnal Jurusan Pendidikan Fisika, 2(1):1-14.

Santoso, R., Darmadi, I. W., \& Darsikin, D. (2016). Pengaruh Model Pembelajaran Berbasis Masalah Berbantuan Media Komputer terhadap Kemampuan Berpikir Kritis Siswa SMA Negeri 5 Palu. JPFT (Jurnal Pendidikan Fisika Tadulako Online), 4(1), 39. https://doi.org/10.22487/j25805924.2 016.v4.i1.5557

Sitanggang, D. R., \& Sari Wahyuni Rozi Nasution. (2018). Pembelajaran Fisika Dengan Problem Based Learning ( PBL ) Untuk Meningkatkan Kemampuan. Jurnal Physics Education, 15-20.

Sugrah, N., Saraha, A. R., \& Djumat, H. H. (2017). Pengaruh Model Pembelajaran Problem Based Learning ( PBL ) Terhadap Keterampilan Berpikir Kritis Peserta Didik Kelas XI IPA SMA Negeri 4 Kota Ternate. Jurnal Saintifik, 1(1), 20-25.

Sunariyati, N. L. P., Agung, A. A. G., \& Dantes, N. (2014). Pengaruh Model Pembelajaran Berbasis Masalah (Problem Based Learning/Pbl) Terhadap Hasil Belajar, Keterampilan Berfikir Kritis Dan Sikap Ilmiah 
Dalam Pembelajaran Fisika Pada Siswa Kelas Xi Ipa Sma Negeri 1 Kuta Tahun Pelajaran 2014/2015. Jurnal Administrasi Pendidikan, 5(1).

Wulandari, T., Kadir, A., Fua, J. La, \& Zainuddin, Z. (2020). Pengaruh Model Problem Based Learning Berbasis Multimedia Terhadap Kemampuan Berpikir Kritis dan Hasil Belajar IPA. Kulidawa, 1(1), 29. https://doi.org/10.31332/kd.v1i1.1806

Yanti, Y., Marzuki, Y., \& Sawitri, Y. (2020). Meta-Analisis: Pengaruh Media Virtual Laboratory dalam Pembelajaran Fisika Terhadap Kompetensi Siswa. Jurnal Penelitian Pembelajaran ..., 6(2), 146-154. http://ejournal.unp.ac.id/index.php/jp pf/article/view/108857

Yoswita, Dewi Fertika dkk. 2013. Pengaruh Model Pembelajaran Problem Based Learning (PBL) Terhadap Kemampuan Berpikir Kritis Siswa. Program Studi Pendidikan Biologi, Fakultas Keguruan dan Ilmu Pendidikan Universitas Lampung. Jurnal Ilmu Pendidikan (online), http://jurnal.fkip.unila.ac.id/, diakses 23 Juni 2021.

Yulianti, E., \& Gunawan, I. (2019). Model Pembelajaran Problem Based Learning (PBL): Efeknya Terhadap Pemahaman Konsep Dan Berpikir Kritis Problem Based Learning (PBL) Learning Model: the Effect on Understanding of Concept and Critical Thinking. Indonesian Journal of Science and Mathematics Education, 02(November), 399-408. 